\title{
China Dynasty Royal Clothing Supply Department-Guang Chusi
}

\section{Zhengang Jiang}

School of Art and Sports, Chosun University, Gwangju, Republic of Korea

Email: 395722866@qq. Com

How to cite this paper: Jiang, Z. G. (2021). China Dynasty Royal Clothing Supply Department-Guang Chusi. Art and Design Review, 9, 90-99.

https://doi.org/10.4236/adr.2021.91008

Received: December 13, 2020

Accepted: February 22, 2021

Published: February 25, 2021

Copyright () 2021 by author(s) and Scientific Research Publishing Inc. This work is licensed under the Creative Commons Attribution International License (CC BY 4.0).

http://creativecommons.org/licenses/by/4.0/

\begin{abstract}
In this paper, Guang Chusi Department, a royal apparel supplier in Qing Dynasty, was selected as the research object. Mainly through the search of historical materials, to have an in-depth understanding of the composition and role of the imperial costume supply department in the Qing Dynasty. The mechanism, officials, craftsmen and functions of the Division are comprehensively analyzed and discussed, to understand the clothing requirements of the Qing Dynasty royal family and the relationship between the administrative departments to understand the royal family's clothing, food, housing and travel. It has important reference value and basis for us to understand the system of royal costume making in detail.
\end{abstract}

\section{Keywords}

China Qing Dynasty, Royal Clothing, Guang Chusi, Craftsman, Seven Zuo, Two Fang, Six Ku

\section{Introduction}

\subsection{Research Reason}

In this paper, Guang Chusi Department, a royal apparel supplier in Qing Dynasty, was selected as the research object. It is mainly through the research of Guang Chusi department to deeply understand the relationship between the supply structure of imperial costume in Qing Dynasty. The mechanism, officials, craftsmen and functions of Guang Chusi will be comprehensively analyzed and discussed. To explore its cultural value and spiritual connotation, as well as its social role and influence on the life of the royal family.

\subsection{Research Problem}

We will focus on Guang Chusi, the department related to the supply of royal 
clothing, namely the royal clothing supply system in-depth analysis. In The Qing Dynasty, most of the clothes were made in a self-sufficient way to meet the needs. However, in the Qing Dynasty, the royal family made costumes through organization, therefore, it is necessary to conduct a thorough and comprehensive study to find out the system of royal costume making and the composition and distribution of costume makers. Through the search of historical materials, it provides a new perspective of research and analysis, so as to understand the content of the clothing demand of the Qing Dynasty royal family and the relationship between their departments and the royal family's clothing, food, housing and transportation.

\subsection{Research Background}

In order to meet the needs of the Qing dynasty royal family, Different from the previous feudal dynasties, the Qing Dynasty set up a special management organization to serve the royal family-imperial household department. As the royal "butler", the imperial household department Official in the imperial family business can be said to be no small matter, the responsibility is very important. For the demand for royal clothes, one of the seven divisions of the imperial household department, Guang Chusi, was the main supplier of royal clothing. The clothing supply in Guang Chusi had a profound influence on the life, politics and military affairs of the royal family. The royal costume was created with an extremely strict hierarchy, and its uses and functions were varied and important for the influence of the state. Moreover, the research on the organization and the costume makers in Guang Chusiis analyzed. We can have an in-depth understanding of the role played by the royal life and its impact, which is of great reference value for us to have a detailed understanding of the royal costume production system.

\section{Qing Dynasty Royal Clothing Supply Department}

The Qing Dynasty was a regime established by ethnic minorities in China. After entering the Customs, it followed the Ming system. However, in the setting of many institutions, it showed the unique style of Manchu. One of the most special institutions is the imperial household department. In the Qing Dynasty, the imperial household department of The Interior always occupied an important position, mainly in charge of the clothing, food, housing and transportation of the emperor's concubines and, more importantly, in charge of the royal finance, providing the production of materials for the emperor's enjoyment. At the same time, the Home Office also engaged in some commercial activities, such as lending money, opening pawnshops, rent official houses and so on.

According to the Records of the Qing Dynasty, "Beijing was founded in the early Qing Dynasty, but there is no record of the time of its establishment." According to the Qing Dynasty History manuscript, "the initial system, the establishment of Internal Affairs, is a divisional department. After entering the customs, set up the internal management office." Therefore, the imperial household 
department was set before the customs.

According to the Records of the Qing Dynasty, "In the eleventh year of Shunzhi, thirteen department were established in the imperial household department, That is, the etiquette department, the eunuch department, the horse department, the implements department, the dress department, the dining department, the treasures and seals department, the ceremonial department, the sword department, the charcoal department, the bell and drum department, the military equipment department, the weaving and dyeing Department. In the eighteenth year of Shunzhi, the government abolished the thirteen departments and restored the building of the imperial household department." During this period, There are mainly responsible for the clothing and jewelry department is Guang Chusi, The department in charge of the selection and evaluation of officers and soldiers and pay is Du Yusi, Responsible for management of sacrificial rites, music, dance and other departments is Zhang Yisi, Manage registered permanent residence, land $\mathrm{mu}$, the branch that receives rural commissariat is Kuai Yisi, The department in charge of building houses and Bridges is the Department of Ying Zhaosi, Administrative penalty department is Shen Xingsi, The cattle and sheep grazing department in Qing Fengsi has seven departments (Kun, 1976). In the first year of The Yong Zheng Reign, the imperial household department Office was authorized as the third-rank department. Officials are of the second-rank. In addition, the imperial household department is responsible for the administration of more than 30 affiliated institutions such as eunuchs, maids of honor and all affairs within the palace in.

In fact, the main functions of the imperial household department of Lords were to administer royal affairs, such as the royal Diet, the dress code, the Treasury, the proprieties, the construction, In addition, the imperial household department also managed the royal farms, livestock, guards, fishing and so on, as well as salt and accepting tribute. After the middle of the Qing Dynasty, there were more than 3000 civilian officials, making it the largest government office in the Qing Dynasty. Therefore, we can see that the duty of the imperial household department is a large imperial household servant agency of "Feng Tianzi's family affairs". The Guang Chusi in the Internal Affairs has a close relationship with the royal costume. Including other departments weaving and dyeing bureau, manufacturing office, such as the three weaving bureau it (Lv, 2014). It was the development of the technology, production capacity and organization of the official institutions that influenced the material quality and craft of the royal costume.

\subsection{Guang Chusi}

In the eleventh year of Shunzhi, the royal family still had a specific department for making clothes, called the Sang-Uiwon. However, in the eighteenth year of Shunzhi, the thirteenth department was abolished, and the building of the Internal Affairs was restored. The main functions of the clothing department were Guang Chusi. Guang Chusi of the first Yu Yongjian. In 16 years of Kangxi, it was 
renamed as Guang Chusi. In charge of the treasurer and the Treasury. Specifically, it is responsible for making and providing clothes for the emperor, empress dowager, empress, concubines, princes and princesses, as well as articles for royal use, gifts and ceremonies (Liu, 2018). It was also responsible for the taxes paid by the imperial family and the gifts of treasures, silks, furs, ginseng and tea, because it was in charge of the royal economy and held the highest position in the Internal Affairs of Lords.

\subsection{Officials of the Guang Chusi}

The Guang Chusi Department was managed by one minister of the Interior every year in turn, and the number of officials varied from the eighteenth year of Shunzhi to the end of Qing Dynasty. Historical records of the Qing Dynasty: "Guang Chusi has four officers in charge of six departments, there are eighteen officials and Yun Wailang, There are 6th-rank siku officials are six people, there were twelve deputy siku officials and eighty kushi officials, There were eighth-rank officials and there were thirty craftsmen (Zhao, 1977).”

\subsection{The Organization of the Guang Chusi}

The Guang Chusi has six ku, seven zuo, two fang departments. The six ku Six are silver, leather, porcelain, satin, clothing, tea management department. There were seven zuo in charge of silver, bronze, dyeing, garments, embroidery, flowers and leather. Two fang namely hat room, sewing room department. Guang Chusi is in charge of the six storehouse cashier, weaving, dyeing bureau, we know that he is also in charge of the three weaving bureau and dyeing bureau departments. Records in the Historical Manuscript of Qing Dynasty "Guang Chusi in charge of the six storehouses cashier, weaving, dyeing bureau" (Zhao, 1977), we know that he is also in charge of the three weaving bureau and dyeing bureau departments (Table 1).

\subsection{Six Ku}

In the eighteenth year of Guang Chusi, there were four departments under the Imperial Administration, namely, silver, leather, satin and clothing departments. In the twenty-eighth year of Kangxi, porcelain and tea departments are collectively referred to as the Six ku. The six ku were mainly responsible for collecting, keeping and providing the silver, jewelry, fur and satin, clothes, hats, boots and socks, ginseng tea, rhinoceros horn and ivory items needed by the emperor (Table 2, Figure 1).

\subsection{Seven Zuo and Two Fang}

In addition to the collection and storage of various items, also assume the responsibility of making various items, is the Guang Chusi of the department of seven zuo and two fang and other departments it is recorded in the current regulations of the Guang Chusi of imperial household department. 
Table 1. Organizations in Guang Chusi.

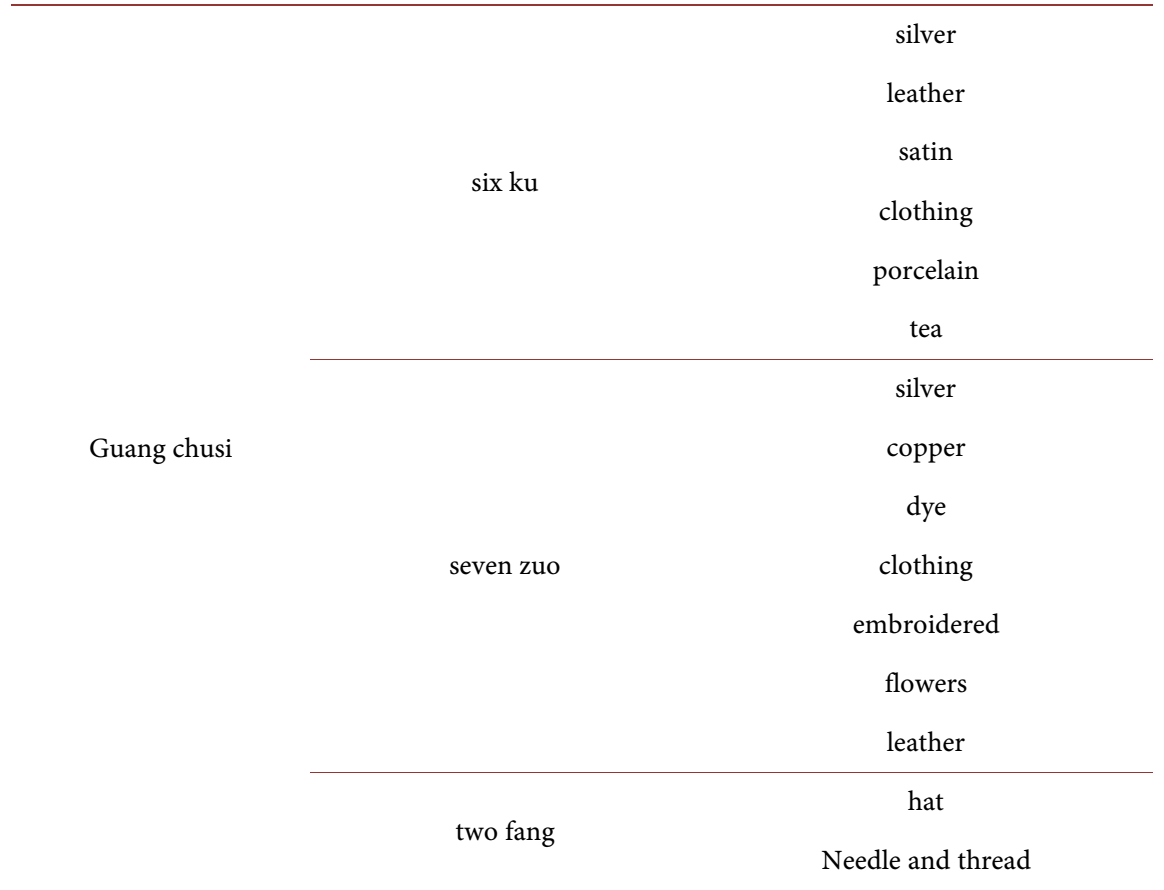

Source: Photocopy of Zhonghua Book Company (2013). Qing Dynasty Ancient books and records. Zhonghua Book Company.

Table 2. Guangzhou department six storehouse management personnel and management of goods.

\begin{tabular}{|c|c|c|}
\hline department & Management personnel and quantity & Collect and keep articles \\
\hline silver & $\begin{array}{l}\text { two yuan wailang, two men is } \\
\text { sixth-rank siku, two treasurers without } \\
\text { official titles, eighteen treasurers }\end{array}$ & $\begin{array}{l}\text { Gold and silver, money making, } \\
\text { jewelry, jade, coral, pine, agate, } \\
\text { amber, gold and silver utensils, etc }\end{array}$ \\
\hline leather & $\begin{array}{l}\text { two yuan wailang, two men is } \\
\text { sixth-rank siku, two treasurers without } \\
\text { official titles, fifteen treasurers }\end{array}$ & $\begin{array}{l}\text { Fox skin, mink, lynx skin, sea dragon } \\
\text { skin, ermine skin and cloth, satin, } \\
\text { blanket, down satin, yarn and ivory, } \\
\text { rhinoceros horn, mat and so on. }\end{array}$ \\
\hline porcelain & $\begin{array}{l}\text { two yuan wailang, two men is } \\
\text { sixth-rank siku, two treasurers without } \\
\text { official titles, eighteen treasurers }\end{array}$ & $\begin{array}{l}\text { Gold and silver vessels, bronzes, } \\
\text { enamels, gold plating, magnetic } \\
\text { copper, tin vessels, etc }\end{array}$ \\
\hline satin & $\begin{array}{l}\text { two yuan wailang, two men is } \\
\text { sixth-rank siku, two treasurers without } \\
\text { official titles, eighteen treasurers }\end{array}$ & $\begin{array}{l}\text { Dragon python satin, gold satin, satin, } \\
\text { palace silk, satin, gauze, damask, twill, } \\
\text { silk, silk piece goods, cotton, etc }\end{array}$ \\
\hline clothing & $\begin{array}{l}\text { two yuan wailang, two men is } \\
\text { sixth-rank siku, two treasurers without } \\
\text { official titles, twenty-four treasurers }\end{array}$ & $\begin{array}{l}\text { Green fox, red leopard, mink, yellow } \\
\text { fox skin, end cover skin, court dress, } \\
\text { boa, as well as female official wear } \\
\text { boa gown jacket skirt, shaman dress } \\
\text { sacrificial ermine jacket and so on. }\end{array}$ \\
\hline tea & $\begin{array}{l}\text { two yuan wailang, two men is } \\
\text { sixth-rank siku, two treasurers without } \\
\text { official titles, eighteen treasurers }\end{array}$ & $\begin{array}{l}\text { Ginseng, tea, incense, paper, wool, } \\
\text { pigment, etc. }\end{array}$ \\
\hline
\end{tabular}

Source: The current regulations of the imperial household department of the Guang Chusi (1937). 


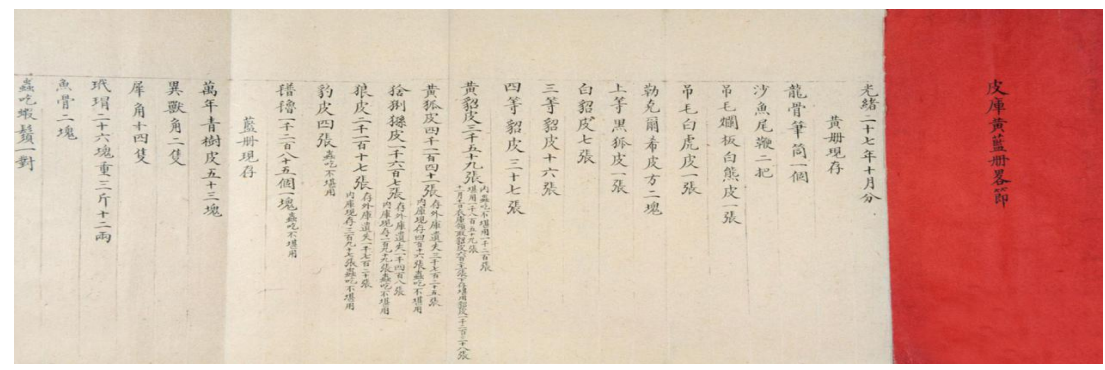

Figure 1. A record of articles kept in a leather vault. Source: https://www.epailive.com.

The silver department is mainly engaged in making gold and silver utensils, jewelry, decorations, etc; The copper department mainly makes all kinds of copper and tin utensils, wire drawing tires and Musical Instruments, etc; The dyeing department mainly dyed and washed silk damask cloth, velvet cotton thread, satin, lamb, deerskin, dragon velvet horse tail, horn lamp piece and silk, elastic cotton and other matters; The embroidery department is responsible for the embroidery of ceremonial robes, gowns and coats, sitting on the back of the hands, bedding and umbrellas, gowns and coats for the inner court, and shops with armour for officials; Flower department to produce various damask, silk, paper, silk, flower supply, banquet flowers, bottle flowers and other matters; The department of clothing is mainly into a variety of royal clothing and so on; The leather department is to wash various kinds of leather sheets to make the horn sky lamp, longevity lamp, holding lamp, etc; the hat fang to make hats and so on; Sewing room weaving for court wear and court clothes for four seasons, boots and socks and other matters (The current regulations of the imperial household department of the Guang Chusi, 1937).

From the name of each department, we know that the main function of each department is to take care of and process various raw materials or repair finished products. There are also strict rules governing the custody of these high-quality necessities. The key of each warehouse shall be sent to the inner court for storage every night. And in the use of goods, if there is a shortage of needed goods, the items can be collected through procedures directly from the department in charge of household finance and the department that manufactures the articles (Ma, 2017).

\subsection{The Craftsman of the Guang Chusi Department}

The craftsman's solution in Ci Hai is "a manual labourer with special skills and skills." By "artisan" in this context, I mean someone with a technical expertise and a certain amount of skill and design, Including Chinese laborers engaged in traditional handicraft production And missionaries from Europe who worked at the court specializing in western craftsmanship (Yang, 2017).

According to the "Current Regulations of the Guang Chusi of imperial household department": There were 1460 craftsmen (21 of them recruited folk craftsmen), and in December of kangxi 43, the craftsmen belonging to the Guang Chusi Department, The Wu bei yuan Department and the Construction 
Department were merged into one place for management. The places where the craftsmen were used in each place made them inform for application. In February fifty-seven the office was authorized to return the craftsmen to the administration of the offices. In March of the fourth year of Emperor Yongzheng, eighty-four craftsmen were approved to be cut; in February of the fifth year, two hundred and sixty-five craftsmen were approved to be cut; in August of the ninth year, eighty-two craftsmen were approved to be cut; in February of the first year of Emperor Qianlong, three craftsmen were approved to be cut; and now there are one thousand and twenty-six artisans in all kinds of artisans, and twenty-one civilian craftsmen were recruited. In October of the eighteenth year of The Reign of Emperor Jiaqing, the department has approved six warehouses for the current recruitment of fourteen craftsmens (The current regulations of the imperial household department of the Guang Chusi, 1937) (Table 3).

In the table, there were 971 court artisans in each department, recruiting 43 civilian artisans. Besides, there were eight hat-making women in the hat department. The Yellow banner and the white Banner respectively have six Mongolian craftsmen. There are one Nei toumu manager, four fu tou mu managers, and

Table 3. The number of managers and craftsmen in the seven zuo of Gwang chusi.

\begin{tabular}{|c|c|c|}
\hline $\begin{array}{l}\text { Department } \\
\text { name }\end{array}$ & $\begin{array}{l}\text { Management personnel } \\
\text { and quantity }\end{array}$ & Artisans and numbers \\
\hline silver & $\begin{array}{l}\text { Two of the eighth-rank } \\
\text { official were craftsmen, } \\
\text { five were Ling cui }\end{array}$ & $\begin{array}{l}\text { Fourteen silversmiths, Seven alchemists, Filigree } \\
\text { twenty-five, Chisel artisan twenty-two, thirty-five } \\
\text { Large objects artisans, fourteen niu zhi artisans, } \\
\text { Four ename artisans, three Kingfisher craft artisans, } \\
\text { eighteen mei xi artisans, Twenty-one jade artisans, } \\
\text { Five craftsmen of the beads, eight a knife artisans }\end{array}$ \\
\hline leather & $\begin{array}{l}\text { one No grade craftsman, } \\
\text { five were Ling cui }\end{array}$ & $\begin{array}{l}\text { One hundred and eighteen Cooked leather artisans, } \\
\text { seventeen Lamp artisans, eight Wear beads artisans, } \\
\text { three Filament artisan, one liao si artisan, one ya } \\
\text { artisans, two bristles artisan, two ying mao artisans, } \\
\text { nine pu lu artisans }\end{array}$ \\
\hline copper & $\begin{array}{l}\text { Two of the eighth-rank } \\
\text { official were craftsmen, } \\
\text { five were Ling cui }\end{array}$ & $\begin{array}{l}\text { five melt the coppersmith, Seven coppersmith, } \\
\text { twenty-five tinsmiths, twelve Wire drawing } \\
\text { artisans, six twist the rope artisans, one workman } \\
\text { who casts bronze, three bo la artisans, one fill in the } \\
\text { mud artisan, three archaize artisans, three xijing } \\
\text { artisans, two pipa artisans }\end{array}$ \\
\hline dye & $\begin{array}{l}\text { one No grade craftsman, } \\
\text { five were Ling cui }\end{array}$ & Thirty craftsmen who dyed it, Twenty bullet cotton \\
\hline clothing & $\begin{array}{l}\text { one of the eighth-rank } \\
\text { official were craftsmen, } \\
\text { five were Ling cui }\end{array}$ & $\begin{array}{l}\text { A hundred and twenty-seven tailors, One hundred } \\
\text { and eight Fur sewing artisans, Thirty hatters, } \\
\text { thirty-nine Weaving artisan }\end{array}$ \\
\hline embroidered & $\begin{array}{l}\text { one No grade craftsman, } \\
\text { six were Ling cui }\end{array}$ & $\begin{array}{l}\text { The embroiderers were an hundred and thirty-five, } \\
\text { Forty-two na artisans }\end{array}$ \\
\hline flower & $\begin{array}{l}\text { one No grade craftsman, } \\
\text { two were Ling cui }\end{array}$ & $\begin{array}{l}\text { Twelve gardeners, ten wire wrapping artisan, four } \\
\text { Washing artisan, one zhao muhua artisan, two String } \\
\text { artisan }\end{array}$ \\
\hline
\end{tabular}

Source: The current regulations of the imperial household department of the Guang Chusi (1937). 
one Mongolian Ling cui manager set up in each of the three banners, And two eunuchs of the needlework department, 486 of needlework women, 481 of boot-stocking women, 70 of purse, 66 of childbearing women, There were 54 women who made saddles, and 14 women who made breastplates. Since craftsmen have different ethnic composition, The Qing Dynasty was ruled by the Manchus, So 80 to 90 percent of Guang Chusi are Manchu artisans, There were only 70, 80 to 100 Han craftsmen from the south (Wu, 1991). Therefore, the identity of the craftsman is different, most of the Manchu craftsman higher pay, by the monthly calculation of wages are guaranteed. Outside craftsman mostly by short-term work, compensation is calculated by "work" (Bi, 2014).

\subsection{The Role of Gung Chusi}

Every time the Emperor went out to visit the tombs and other matters, the various departments of the Guang Chusi Department sent officials and craftsmen to accompany him with the crowns and ribbons needed by the Emperor for sacrifice and living goods.

Every year when the Emperor is in the Temple of Heaven, the Temple of The Ancestors, the Altar of the Taimiao and other activities, the Guang Chusi department of the various departments of the craftsmen in advance to prepare a variety of lights, door lights delivered to the guard or defense departments.

Every time the Emperor went to the South Garden of the Old Summer Palace, all departments in Guang Chusi sent officials and artisans with silver, cloth, fur, paper, clothing and other articles of daily use to follow on duty.

Responsible for sorting out the gold, silver, satin, silk, leather, copper, tin, lead and other articles and the emperor's gifts every month, and write up on the next month.

The east Pearl, which is responsible for the annual tribute paid to the foreign lands, shall be inspected and classified by the Ministry of Internal Affairs and the Ministry of Work, and entrusted to the department in charge of silver for safekeeping.

Responsible for the ginseng sent to Sheng jingning Ancient tower by the general manager of the home office monitoring, testing, grading, and collected in the tea department.

Responsible for the sauron place, Ning Guta sent mink by the ministry of internal affairs and the ministry of household acceptance, grading deposited in the silver department.

Responsible for the emperor's preparation and distribution of gifts.

Be responsible for keeping the goods such as silk piece goods, thick and thin cloth, gaoli cloth, tea, preserved meat and all kinds of fur etc. handed in by various places.

Responsible for overseeing the firing of porcelain for the chamber.

To be responsible for the supervision of the three weaving Bureau, drawing up matters such as the number, size, color and pattern of satin lifting, etc. 


\section{Summary}

This paper reconstructed the overall framework of Guang Chusi department from the perspective of archives and historical materials, and narrated the basic situation and management system of Guang Chusi as the main body. Guang Chusi mainly planned and prepared for the royal family's daily activities, sacrifices, inspections, weddings and other important royal festivals. It can be seen that as a department especially in charge of clothing supply for the royal family in the Qing Dynasty, Guang Chusi functions were much diversified and its status in the whole court was also very high. The subordinate departments of Guang Chusi have a very fine division of labor. There are special departments responsible for the procurement of raw materials, Fabric pattern, fabric weaving, clothing making, etc. Guang Chusi is not only responsible for the management of the garments in the palace, but also the management of the weaving of the external departments, such as Jiangnan three weaving, internal weaving and dyeing bureau, etc., which are also coordinated by the Guang Chusi Department. Guang Chusi not only supervises weaving, but also takes care of the clothing and jewelry of the royal family. It also takes care of tribute items from different countries and regions. As a result of weaving clothes for the royal family, a lot of artisans work, through the analysis of historical data, the scale of artisans is very large. There are thousands of craftsmen in Guang Chusi serving for the royal family. The classification of craftsmen is also very detailed and diversified. For example, they are divided into intrauterine craftsmen and outworkers, as well as artisans of different nationalities. It can be seen that the absorption of craftsman by the Guang Chusi Department is diversified. The study of Guang Chusi allows us to clearly see the size of the Qing Dynasty royal family's clothing demand and the richness of clothing category. It gives us a deeper understanding of the life, economy and cultural customs of the Qing dynasty royal family. All of these have good research and reference value.

\section{Conflicts of Interest}

The author declares no conflicts of interest regarding the publication of this paper.

\section{References}

Bi, C. L. (2014). From the Archives of the Qing Court, See the Organization and Management of Enamel Craftsmen. Research on Central Plains Culture, 3, 96-102.

Kun, G. (1976). Examples of Qinding Da Qing Dynasty Ancient Books and Records. Taibei: Xin Wenfeng Publishing Co. LTD.

Liu, F. (2018). Research on the Dress of Royal Family and Aristocrats in Early Qing Dynasty. Jinan: Shandong University Press.

Lv, J. (2014). Jiangnan Three Weaving Bureau for the Royal service. The Forbidden City, 4, 118-123.

Ma, B. T. (2017). Research on the Silver Bank of Guang Chusi in Qing Dynasty and Its Income and Expenditure. Master's thesis, Haerbin: Heilongjiang University.

Photocopy of Zhonghua Book Company (2013). Qing Dynasty Ancient books and 
Records. Beijing: Zhonghua Book Company.

Guang Chusi (1937). The Current Regulations of the Imperial Household Department of the Guang Chusi.

Wu, Z. Q. (1991). Qing Dynasty Manufacturing Department of Machinery and Artisans. Historical archives, 4, 79-86.

Yang, H. N. (2017). Research on the Craftsman of Qing Palace Manufacturing Department. Master's Thesis, Wuhan: Wuhan University.

Zhao, E. X. (1977). Qing Dynasty History Manuscript. Beijing: Zhonghua Book Company. 